症例報告

\title{
脳幹部海綿状血管腫に対する内視鏡手術
}

\author{
秋 禎樹1)，竹内 和人 ${ }^{1)}$ ，渡邊 督2)，永田 雄一2)，若林 俊彦1)
}

1）名古屋大学医学部附属病院脳神経外科, 2) 名古屋第二赤十字病院脳神経外科

\section{Endoscopic Resection of Brain Stem Cavernous Malformations (BSCMs) : Two Illustrative Cases and Surgical Methods Employed}

\author{
Jonsu Chu, M.D. ${ }^{1)}$, Kazuhito Takeuchi, M.D. ${ }^{1)}$, Tadashi Watanabe, M.D. ${ }^{2}$, Yuichi Nagata, M.D. ${ }^{2)}$, and \\ Toshihiko Wakabayashi, M.D. ${ }^{1)}$ \\ 1) Department of Neurosurgery, Nagoya University, 2) Department of Neurosurgery, Japanese Red Cross Nagoya Daini \\ Hospital
}

Brain stem cavernous malformations (BSCMs) are associated with a high rate of hemorrhagic events. Though BSCMs that bleed or grow in size are indicated for resection, the surgical procedure usually involves a high risk of damage to the normal brain. We successfully achieved total resection, in two cases of symptomatic BSCMs, using a neuroendoscope. The BSCM was localized in the ventral part of the pons in the first case and in the middle cerebellar peduncle in the second case. In both cases, diffusion tensor images (DTI) were taken with an MRI to confirm the localization of the BSCM in relation to the pyramidal tracts. We resected the BSCMs using a 'wet field method' which renders the surgical fields clear without using suction tubes. The wet field provides the operator with an increased range of manipulation even in a tight space.

With our technique, the indications of endoscopic surgery have widened. We have shown that neuroendoscopic surgery can safely and effectively replace conventional craniotomy for certain brain stem lesions.

(Received August 4, 2016 ; accepted October 5, 2016)

Key words : endoscope, brain stem cavernous malformation, wet field, diffusion tensor image

Jpn J Neurosurg（Tokyo）26:216-223, 2017

\section{緒 言}

脳幹部海綿状血管腫（brain stem cavernous malformation：BSCM）はまれな疾患であり，後頭蓋窩の血管奇形 のうちの $13 \%$ といわれている. BSCM の年間出血率は 2.3〜 6.8\%，再出血率は 5.0〜 21.5\% と高い出血率である とされている715).

BSCM に対する外科的治療の morbidity rate/mortality rate はそれぞれ，5.0２7.7\%，0６.3\%である2)という報
告があり，手術適応はきわめて慎重に決定されるべきで ある。

今回, 筆者らは 2 例の BSCM に対して内視鏡的摘出術 を行ったため文献的な考察を交え報告とする.

\section{症例提示}

1 Endoscopic transnasal transclival approach 患 者：64 歳, 女性. 


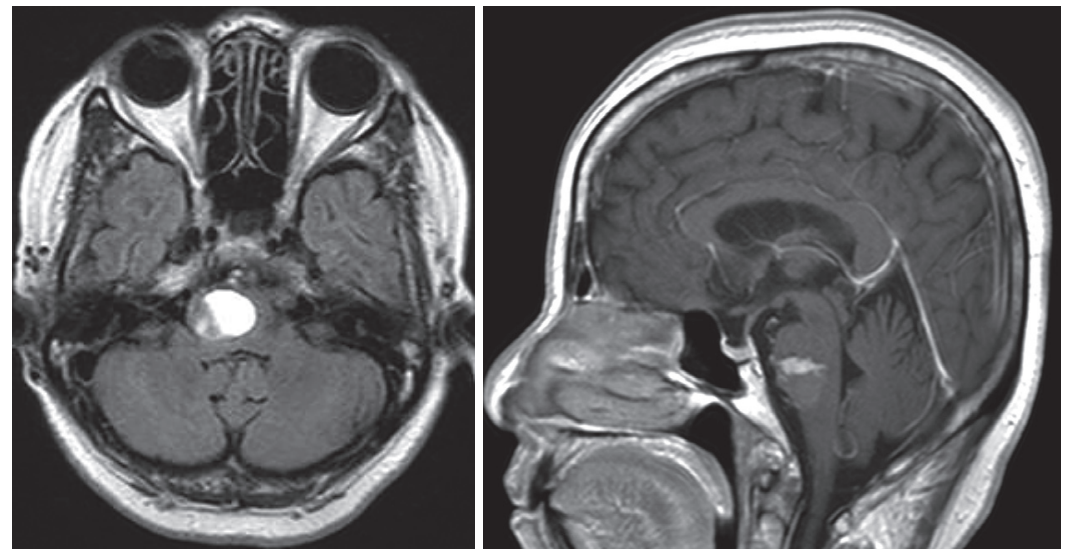

Fig. 1 Preoperative cranial MRI

A T1 weighted MRI shows a brain stem cavernous malformation (BSCM) of the right pons.

現病歴：複視を主訴に来院された。来院時診察上，右 眼の外転神経障害を呈していた。その他，特記すべき神 経学的脱落所見はみられなかった。頭部 MRIでは右橋部 に出血を伴う mass を認めており BSCM と診断した。そ の後, 外来通院で経過観察していたが, 徐々に左不全麻 痺をきたすようになり，左上下肢 MMT $2 / 5$ まで悪化し た。頭部 MRI では右橋部の mass は増大傾向にあり, 出 血を繰り返していることが示唆された（Fig. 1).

治療決定：症候性および出血傾向の BSCM であり，外 科的治療を要すると判断した。画像上, 病変は脳幹部腹 側に存在しており, 硬性内視鏡を用いた経鼻的アプロー チ下での摘出術をプランニングした.

MR diffusion tensor image（DTI）を用いた tractography を作成し, BSCM と錐体路の位置関係を同定した(Fig. 2). 錐体路は BSCM の左右に分かれるように走っているの が確認された。脳底動脈は脳幹前面においてやや右側へ 蛇行する所見であり，脳底動脈と左錐体路との間からの アプローチが啇していると考えられた。

手 術: 術前にDTI で作成した tractography のデータ をナビゲーションシステムに連動させ, 術中, 常にナビ ゲーションで BSCM や錐体路の同定が可能な状態とし た。ナビゲーション以外にも神経刺激モニタリングとし て somatosensory evoked potential (SEP), motor evoked potential（MEP）を用いることとした.

手術は $4 \mathrm{~mm}$ 径の硬性内視鏡 (Endoarm $\mathrm{HD}^{\circledR}$, Olympus, Tokyo）を用いた。内視鏡下に経鼻中隔アプローチとし た。経蝶形骨洞およびその先の clivus を削り, 脳幹部硬 膜を縦に切開した。脳幹表面を露出させ, 画面中央に BSCM を確認した。 BSCM の周囲には画面左側（患者右 側）に脳底動脈が縦走しており, その穿通枝はBSCM の
上方，下方を横走していた。術前の tractography で同定 されていた錐体路の走行と一致するょうにBSCM の外 側には白色線維が縦走していた。術中神経モニタリング (直接電気刺激)を用いて白色線維が錐体路であることを 確認した。BSCM が脳幹表面に突出している部位より進 入し，BSCM 本体の摘出を開始した。摘出腔の上方には venous anormalyが同定され，損傷しないように摘出を進 めた（Fig. 3). Dry field method と wet field method（後 述）を交互に繰り返し，肉眼的な全摘出に終わった。硬 膜開放部の縫合には，multi-layer closure（後述）を用い た.

術後経過：術後より ICUにて鎮静，捙管管理とした. CT 上，BSCM の摘出腔内やその他の正常組織に新たな 出血は認めなかった。術後 2 日目には抜管し, 意識清明 であった。術前の右上下肢の脱力は遷延がみられたが, 術後 3 日目より徐々に改善傾向にあり, 術後 7 日目には 右上下肢とも MMT 4 であった。術後 14 日目には, 軽度 の失調性は残ったが歩行可能状態であった。現在，手術 より 12 カ月が経過したが BSCM の再発なく，自立した 生活を送っている (Fig. 4).

\section{Endoscopic subtemporal approach}

\section{患 者: 28 歳, 男性.}

現病歴：めまいを主訴に近医受診, MRI で橋背側に出 血を伴う病変を認めており, 橋背側の BSCM と診断され た。経時的なフォローの最中に右側の感覚障害をきたす ようになり，MRIではBSCMに接するょうに橋背側に出 血を繰り返す所見を呈していた（Fig. 5)。複数回の出血 エピソードを認め手術適応と判断され当院紹介となった.

治療決定：感覚障害の増悪および血腫の増大を伴う 

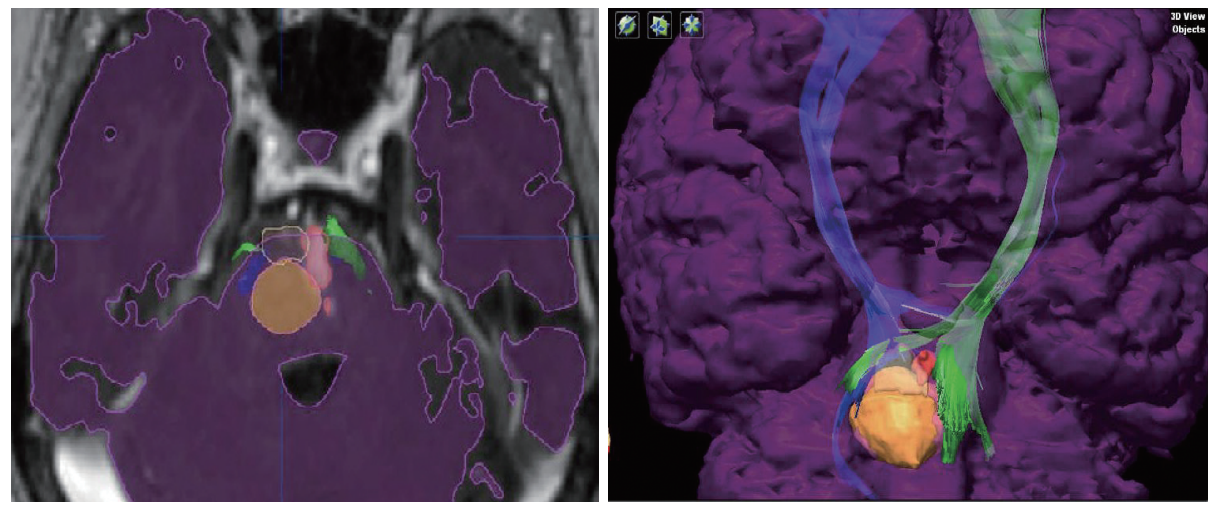

Fig. 2 Preoperative diffusion tensor images (axial view and 3-dimensional image)

Yellow indicates the hematoma, green the left pyramidal tract, and blue the right pyramidal tract.
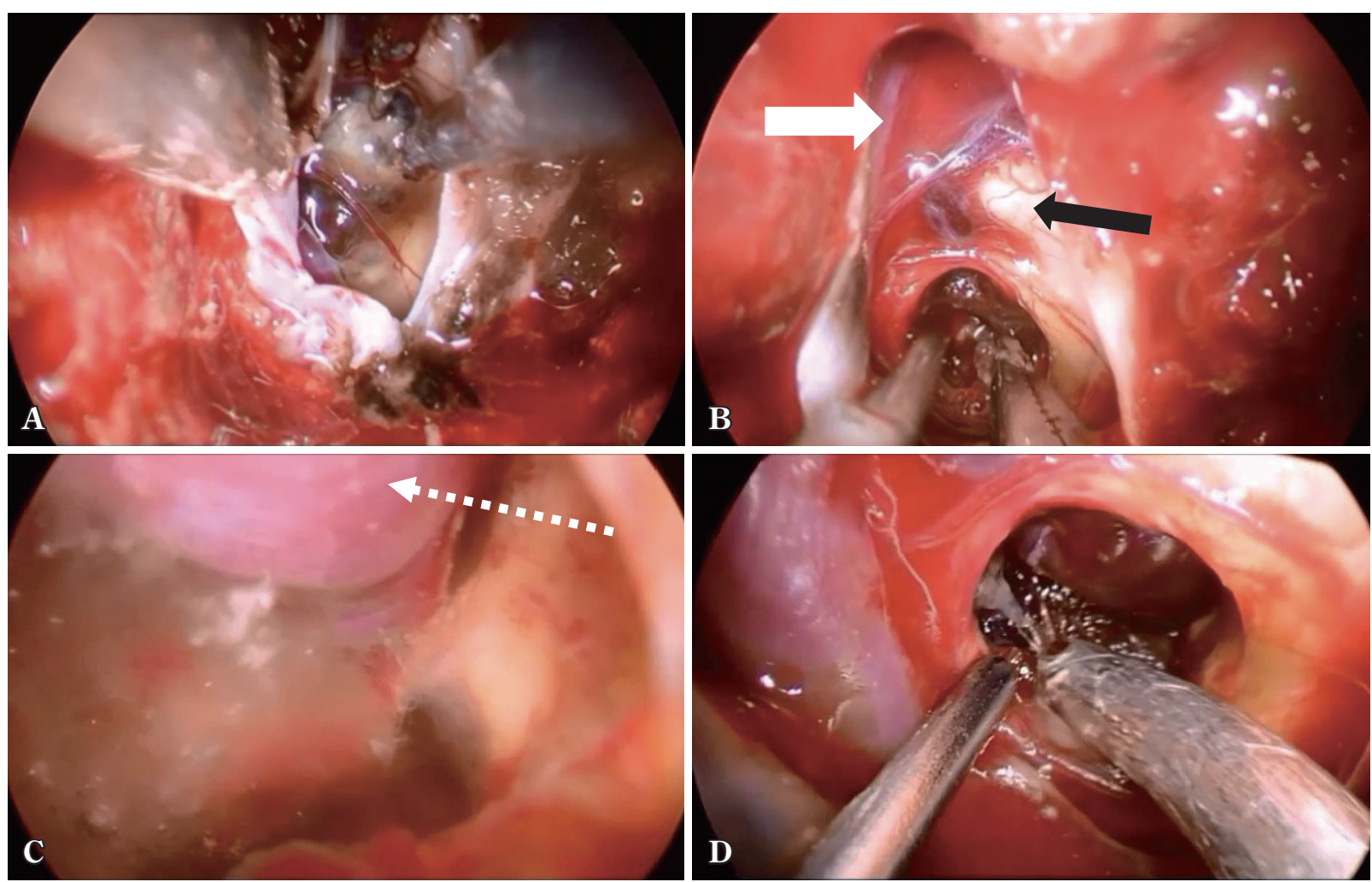

Fig. 3 Operative procedure

A : After drilling the clivus and opening the dura mater, the BSCM is confirmed and coagulated with bipolar forceps.

B : Evacuation of the cavernous angioma. The white arrow indicates the basilar artery and the black arrow the left pyramidal tract.

$\mathrm{C}:$ The cavity of the evacuated lesion viewed with the wet field technique. The dotted arrow indicates a venous anormaly.

D : Evacuation of the residual lesion with a dry field technique

BSCM であり，筆者らは外科的治療の必要性を検討し た。DTIを用いて BSCM および錐体路の局在を確認し， 左側の錐体路はBSCM の前方を走っていることが確認 された (Fig. 5)。術者と BSCM の間に錐体路が走行して
いなければ橋部にシースを挿入することができ，内視鏡 を用いた摘出が可能であると考えられた。 よって今回筆 者らは, 左橋部外側からのアプローチが適していると判 断した. 

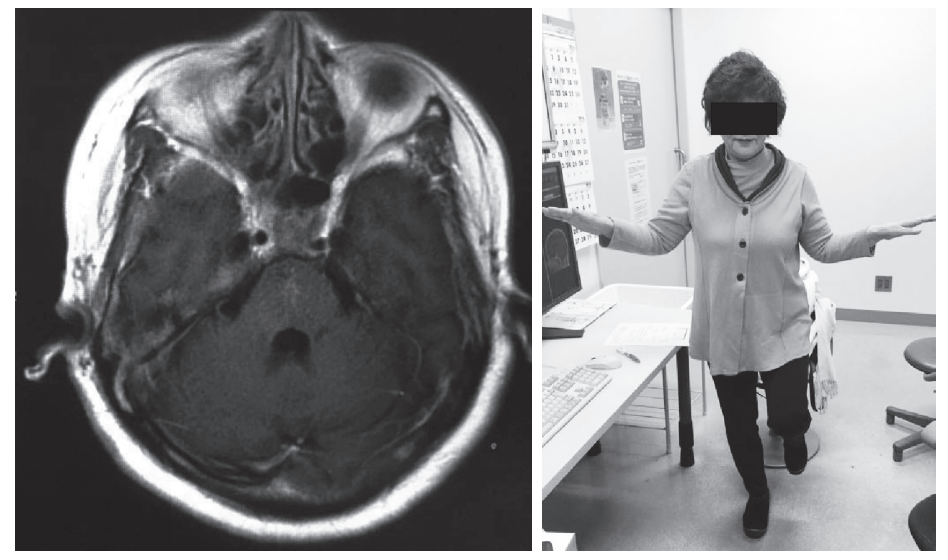

Fig. 4 At 6 months after the operation, cranial MRI and picture

The patient's MRI shows no residual lesion. She was also free of any neurological dysfunction.

手 術：症例 1 同様にナビゲーションシステムおよ び, 神経刺激モニタリングとして SEP, MEPを用いた。 体位は右 lateral position として, 頭位が右側 90 度の状態 となるよう頝部回旋を行った. 左側頭部に約 $3 \mathrm{~cm}$ 径の小 開頭を置き, 以降内視鏡下に subtemporal approach を 行った。左側頭葉下面と小脳テント間を豩離し, 小脳テ ントを切開し左橋部外側面に到達した。術中神経モニ夕 リング（直接電気刺激）を用いて脳幹部穿刺部位に錐体 路が通っていないことを確認したのち, 左滑車神経, 上 小脳動脈などを損傷しないように橋外側（Fig. 6 の左上 の黄色の円)に切開を加えた. $6 \mathrm{~mm}$ 径の Neuroport Mini ${ }^{\circledR}$ （Olympus）をナビゲーションガイド下, 鏡視下に橋外側 部へ向けて挿入した. $2.7 \mathrm{~mm}$ 径の硬性内視鏡を用いシー ス内の空間を利用して，摘出を開始した．Wet field method を用い摘出腔内を広げることで BSCM 全体を確 認し, piece by piece に細径の針子，バイポーラなどを用 いながら行った。摘出腔の止血および BSCM の残存がな いことを確認し手術終了とした（Fig. 6)。

術後経過：術直後より覚醒良好であり, 新たな錐体路 障害は認めなかった。術後の CT で, BSCM 摘出腔内に 血腫は認めなかった。術後 3 日目まではめまい症状を認 めていたが徐々に改善傾向にあり, 術後 10 日目には自 力歩行可能となった. 現在手術より 18 力月が経過した が BSCM の再発なく，自立した生活を送っている（Fig. 7).

\section{考 察}

脳幹部病変に対する外科的治療は，その病変が脳深部 に局在すること, 脳幹には重要な神経核や神経線維が多
数存在することといった因子により, 術後に重篤な神経 学的合併症をきたすことが予想される。そのため脳幹部 病変への治療戦略はきわめて慎重に決定されなければな らない.

\section{1 アプローチの決定, 手技}

BSCM の局在はほとんどが脳幹の外腹側もしくは背側 である ${ }^{6)}$. BSCM に対する外科的治療は開頭術が主流で ある.

Brown $ら^{1)}$ は, BSCM の摘出の際, 病変部の中心点と 正常の脳幹組織表面が最も近くなる点を結ぶ線上からア プローチするのが好ましいとする “two-point method”を 提唱している。この method を基に BSCM が(1)中脳に存 在する場合は frontotemporal transsylvian approach, subtemporal approach, (2)橋部の場合は transpetrosal presigmoid approach, transvermian approach, supracerebellar infratentorial approach, (3)延髄の場合は far-lateral transcondylar approach，などといったさまざまなアプローチ 方法が提唱されてきた、今回筆者らは, 症例 1 では endoscopic transnasal transclival approachを, 症例 2では endoscopic subtemporal approachを採用している。どちらの症 例も “two-point method” に沿ったアプローチ方法であ る。この method は, 進入経路となる正常の脳幹組織に 対するダメージを最小限に留められるという利点があ る。脳幹部の腹側に局在をもつ BSCM に対する摘出法 は，2001 年に Reisch ら ${ }^{13)}$ が顕微鏡を用いて, transoral transclival approachにより摘出を行っている. 内視鏡を 用いた経鼻的アプローチを用いた摘出術としては 2012 年に Kimball ${ }^{6)}$ らが, 2015 年に Dallan $ら^{3)}$ や Linsler $ら^{8)}$ が それぞれ報告して，良好な摘出を得ている，筆者らの症 

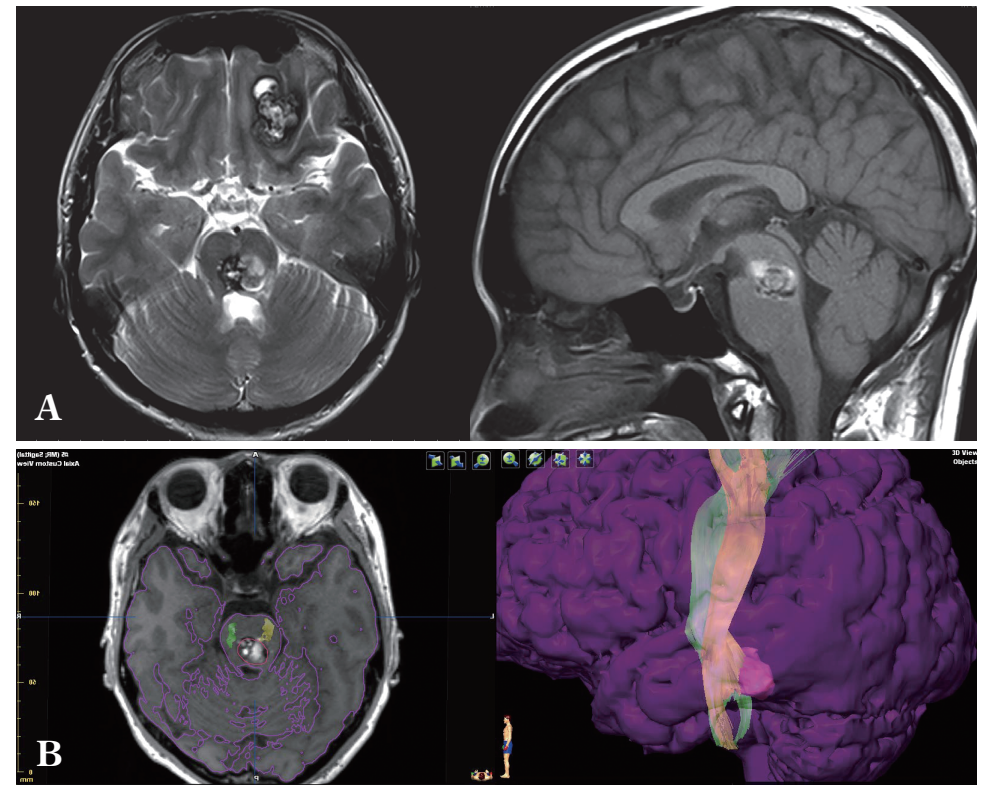

Fig. 5 Preoperative cranial MRI and diffusion tensor images

A : MRI shows a BSCM in the dorsal part of the pons.

B : Preoperative diffusion tensor images (axial view and 3-dimensional image). Red indicates the BSCM, green the right pyramidal tract, yellow the left pyramidal tract.
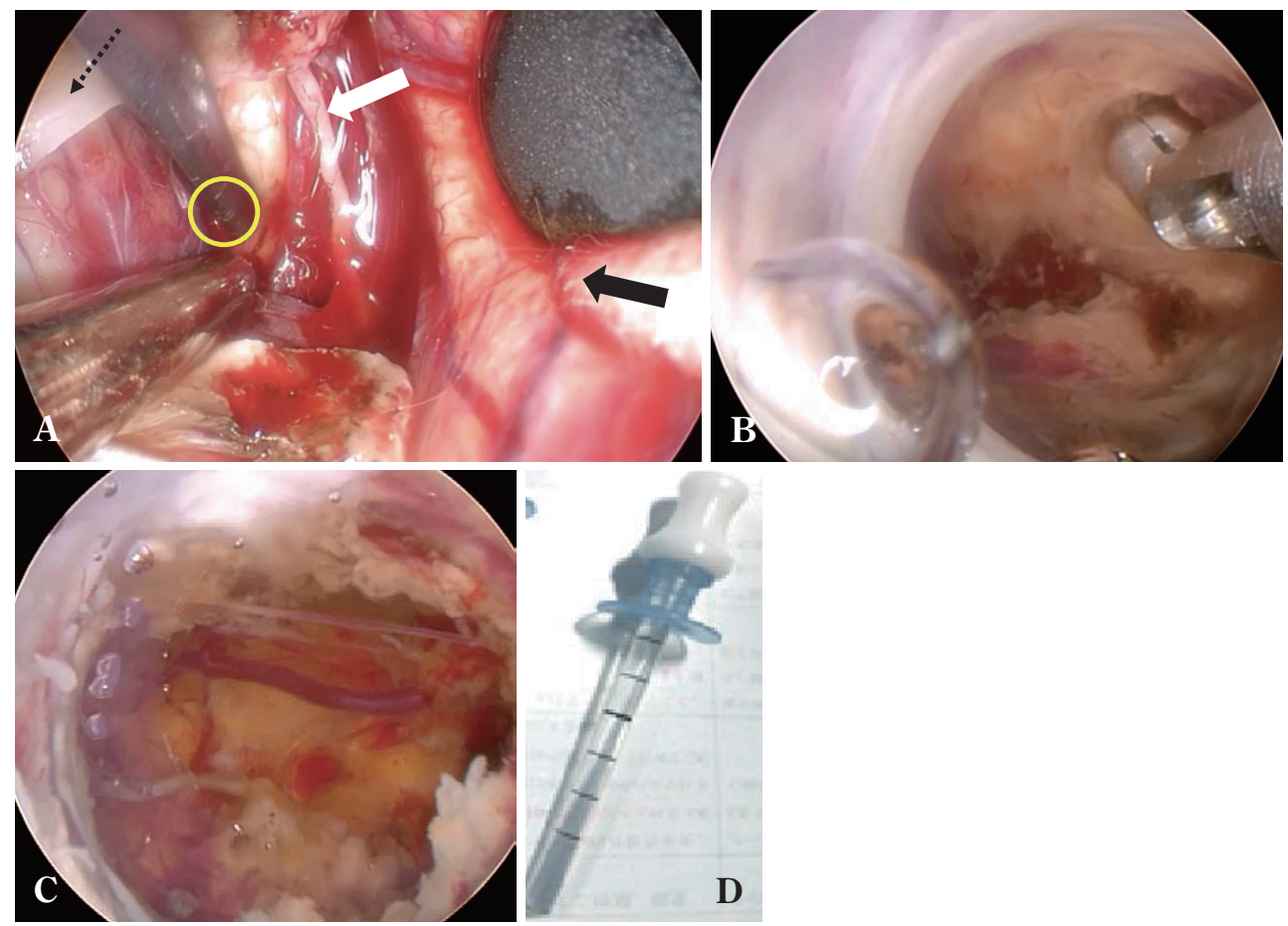

Fig. 6 Operative procedure

A : Left subtemporal craniotomy is performed and the cavity between the left temporal lobe (black solid arrow) and the cerebellar tent (black dotted arrow) is opened. After cutting the cerebellar tent (black dotted arrow), the left lateral part of the pons is confirmed. The white arrow indicates the left trochlear nerve. A small corticotomy was made in the left lateral part of the pons (yellow ring).

B : The BSCM is evacuated with forceps using the wet field technique.

C : The cavity after the BSCM was evacuated.

D : Neuroport Mini ${ }^{\circledR}$ (Olympus, Tokyo). 

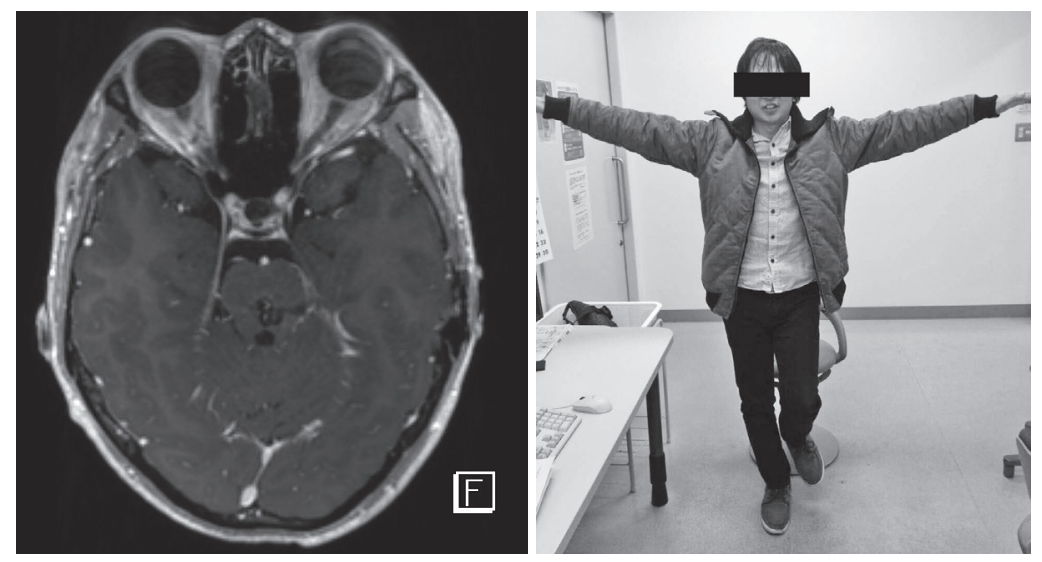

Fig. 7 At 6 months after the operation, cranial MRI and picture Contrast enhanced MRI reveals no recurrence of the lesion. After the operation, The patient was free of any neurological dysfunction.
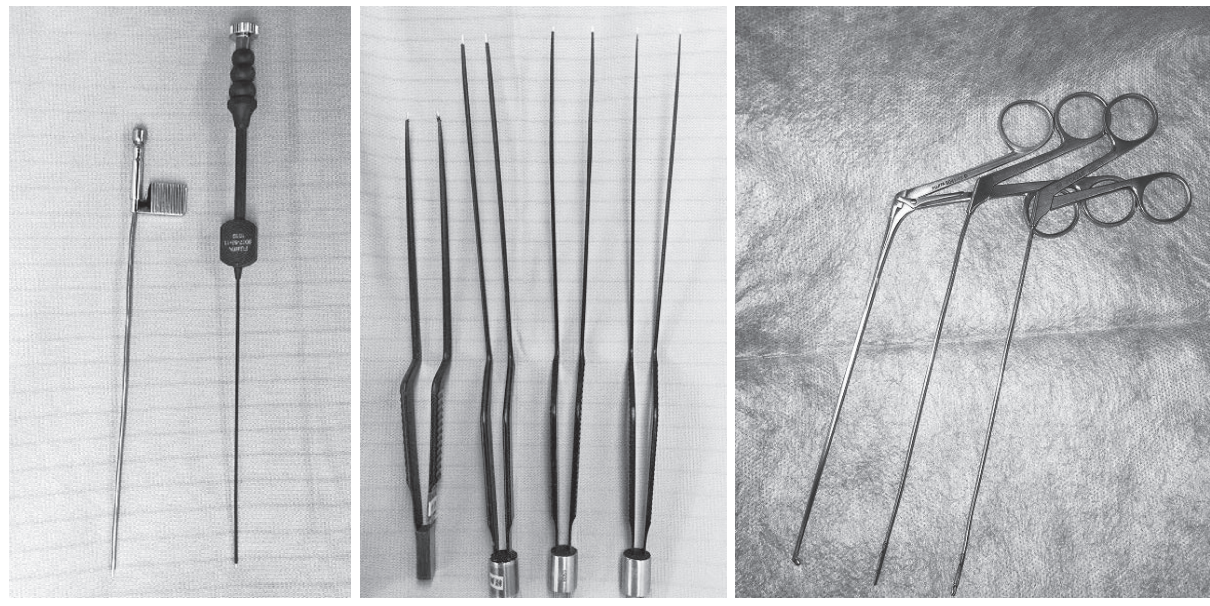

Fig. 8 New instruments for endoscopic surgery

例においても同様なアプローチを行っており，病変によ り近い部位からの摘出が奏効したと考えられる。しかし 脳幹部病変に対する経鼻的アプローチの際, 手術を困難 にする因子の 1 つには, basilar venous plexus からの出血 がある. Basilar venous plexusの平均厚は $1.1 \mathrm{~mm}$ であ $り^{17)}$, basilar venous plexus は, 上方では clivus の背側に 位置しており，下方では tectorial membraneを覆うかた ちで存在している. Transnasal transclival approachを行う 際には脳幹部へ到達する前に必ず通らなければならない 構造物であり, この静脈叢からの出血は必発と考えてよ い．筆者らはこの問題を解決すべく, 静脈叢を半層切開 し，硬膜切開部位から離れた部位に少しずつ堤防を作る ように静脈叢内にフィブリン糊付きサージセル ${ }^{\circledR}$ を敷き 詰めていくことで止血を得た。

脳幹病変を経鼻的に操作する場合, 術中の髄液漏は必
発である。術後の髄液漏やそれに付随する髄膜炎を予防 するためにも, 脳幹部操作後の髄液漏防止処置は重要で ある.

Snyderman $ら^{14)}$ は, vascularized pedicled flaps を用いた 硬膜閉鎖が確立されて以降，術後髄液漏の発生率は下 がっていると言及している，筆者らは，脳幹部操作終了 後に硬膜閉鎖目的として腹直筋膜を用いての multi layer closure $^{12) 16)}$ を行っている。硬膜下には腹部より採取した 脂肪を充填し，その表層では硬膜と腹直筋膜を縫合して いく方法である。この方法は術中の nasoseptal flaps や術 後の腰椎ドレーンを必要としない.

\section{MR diffusion tensor image (DTI)}

筆者らは今回, 2 症例の術前にDTI を用いた tractography 作成した. BSCM と錐体路との位置関係をあらか 
じめ評価しておくことで，術中の神経モニタリング （SEP，MEP）の手助けになると考元る.

Flores $ら^{4)}$ は, 症候性の BSCM の患者 11 例に対して開 頭下摘出術を施行しており, その際に全例 DTI を用いた tractography を作成し, 術前, 術中の評価を行っている. 彼らは術前より (1)corticospinal tract，(2)medial lemniscus and medial longitudinal fasciculus, (3)inferior cerebellar peduncle, (4)middle cerebellar peduncle, (5)superior cerebellar peduncle の 5 つの神経伝達路を同定し, 手術に臨 んでいる. 6 例 (54.5\%) の患者は術後早期に自宅退院で きており，残る5 例 (45.5\%) もリハビリテーション病 院での治療を経て最終的には自宅退院できている.

同様に筆者らの症例も術前よりみられた神経学的症候 は術後早期に改善している。筆者らは tractography を術 前の治療戦略の決定（アプローチの決定，錐体路との位 置関係の把握）に用い，また，術中にはナビゲーション としても有用であった.

このように術前に tractography を作成して, 術者と病 変部の間に錐体路などの重要な神経線維がどのように走 行しているかを確認することは必須である，筆者らの症 例のように神経線維が術野の中心に存在していないよう な病変の場合, 内視鏡摘出術のよい適応であると考元る.

\section{3 手術機器}

筆者らは症例 2 の術中に Neuroport Mini（Fig. 6D）を 用いて摘出操作を行っている。このデバイスはもとも と, 深部の頭蓋内出血に対する内視鏡下血腫除去術用に 作成された小径の透明シースである。2000 年, Nishihara $ら^{11)}$ は頭蓋内出血に対する内視鏡下血腫除去術の際に透 明シースを用いることで正常脳への侵襲を最小限にしつ つ，かつ有効な血腫の除去が可能であると報告した。今 回の症例 2 に扮いても同様なことがいえる。脳深部への 到達の際には，その手前にある脳組織の retraction が必 須となる。筆者らの症例では, $6.0 \mathrm{~mm}$ 径といった小径の シースを用いることで周囲構造物への retraction を最小 限に抑え病変部への到達が可能であった。ただし，小径 シース内手術では working space が狭いという問題点が ある、筆者らは Fig. 8 にあるような極細の吸引管（フジ 夕医科器械)，極細鉗子 (B. Braun Aesculap Japan) を用 いた。また筆者らは極細バイポーラ (フジ夕医科器械) を開発した. $6 \mathrm{~mm}$ 径の Neuroport Mini の中に $2.7 \mathrm{~mm}$ 径 の硬性内視鏡を挿入しての操作であるため, 手術器具を 細くすることでシース内での両手操作を可能とした。 こ れによって，小血管からの出血に対する止血や病変の剝 離の精度を増すことができた。

\section{Dry field method と wet field method}

Dry field method とは， tract 内やシース内に吸引管を 常に挿入した状態で，手術操作を行う technique のこと である。開頭術でもいえることであるが，止血操作や剝 離操作の際は通常，吸引管を用いて術野内の血液を吸引 除去しながら行われる。内視鏡下でもこの method は可 能であり片手に bipolar forceps，もう片手に吸引管を持 ち，止血，剝離を行うことができる。これに対比して wet field method は，持続的に人工髄液（アートセレブ®，大 塚製薬）を灌流させ，tract 内やシース内を液体で満たす 方法である. Wet field method は内視鏡下血腫除去の手術 中に人工髄液の洗浄と吸引のバランスを巧みに調整し, 血腫腔を拡大し止血する Nagasaka ${ }^{10)}$ の報告や，下垂体 腺腫の経鼻内視鏡下腫瘍摘出の手術中に鞍内の残存腫瘍 を洗浄で除去かつ出血点を確認する Locatelli $ら^{9)} の$ diving technique と同様である。藤田ら ${ }^{5)}$, 渡邊ら ${ }^{18)}$ は, 術中 に wet field method 用いることで病変摘出腔が広がり, 病変の視認に優れていると言及している.

筆者らは両症例において wet field method を取り入れ た。術中に病変を摘出していくと，頭蓋内圧の影響によ り摘出腔が徐々に狭くなっていく，Fig. 3C，6C は実際の wet field method の写真である. Wet fieldにすることで摘 出腔が広がり出血点を容易にみつけ出すことが可能で あった。さらに今回筆者らは，動脈圧ラインに用いられ る加圧バッグからの irrigation を利用することで灌流量 を一時的に増加させ，出血中であっても視界を確保し， 出血点を確認することが可能であった．また先端露出の 少ないバイポーラは wet field 下においても良好な凝固を 可能とした。

\section{結 語}

脳幹部海綿状血管腫に対する外科的治療は，必ずしも よい成績を残せる治療ではなかった。しかし，内視鏡機 器の発達, 周辺機器の改良, 技術革新に伴い, より安全 に摘出することが可能となっている.

\section{COI 開示文}

著者全員は日本脳神経外科学会への COI 自己申告の登録を 完了しています。本論文に関して開示すべきCOI はありませ ん.

\section{文 献}

1) Brown AP, Thompson BG, Spetzler RF: The two-point method : evaluating brainstem lesions. BNIQ $12: 20-24$, 1996. 
2) Chen L, Zhao Y, Zhou L, Zhu W, Pan Z, Mao Y : Surgical strategies in treating brainstem cavernous malformations. Neurosurgery 68:609-620; discussion 620-621, 2011.

3) Dallan I, Battaglia P, de Notaris M, Caniglia M, Turri-Zanoni $\mathrm{M}$ : Endoscopic endonasal transclival approach to a pontine cavernous malformation : case report. Int J Pediatr Otorhinolaryngol $79:$ 1584-1588, 2015.

4) Flores BC, Whittemore AR, Samson DS, Barnett SL: The utility of preoperative diffusion tensor imaging in the surgical management of brainstem cavernous malformations. $J$ Neurosurg 122: 653-662, 2015.

5）藤田浩二, 矢本利一, 中尾直之：脳内出血に対する内視 鏡下血腫除去術の工夫一Diving technique を用いた dry field と wet fieldの使い分け一. 脳卒中の外科 $42: 383^{-}$ $387,2014$.

6) Kimball MM, Lewis SB, Werning JW, Mocco JD : Resection of a pontine cavernous malformation via an endoscopic endonasal approach: a case report. Neurosurgery $\quad \mathbf{7 1}$ (1 Suppl Operative) : 186-194, 2012.

7) Kondziolka D, Lunsford LD, Kestle JR: The natural history of cerebral cavernous malformations. J Neurosurg 83 : 820-824, 1995.

8) Linsler S, Oertel J : Endoscopic endonasal transclival resection of a brainstem cavernoma : a detailed account of our technique and comparison with the literature. World Neurosurg 84:2064-2071, 2015.

9) Locatelli D, Canevari FR, Acchiardi I, Castelnuovo P: The endoscopic diving technique in pituitary and cranial base surgery: technical note. Neurosurgery 66: E400-E401, 2010.

10) Nagasaka $T$, Inao $S$, Ikeda $H$, Tsugeno $M$, Okamoto $T$ : Infla- tion-deflation method for endoscopic evacuation of intracerebral haematoma. Acta Neurochir (Wien) 150:685-690, 2008.

11) Nishihara T, Teraoka A, Morita A, Ueki K, Takai K, Kirino $\mathrm{T}:$ A transparent sheath for endoscopic surgery and its application in surgical evacuation of spontaneous intracerebral hematomas. Technical note. J Neurosurg 92:10531055, 2000.

12) Raza SM, Schwartz TH : Multi-layer reconstruction during endoscopic endonasal surgery: how much is necessary? World Neurosurg $83:$ 138-139, 2015.

13) Reisch R, Bettag M, Perneczky A: Transoral transclival removal of anteriorly placed cavernous malformations of the brainstem. Surg Neurol 56: 106-115, 2001.

14) Snyderman $\mathrm{CH}$, Pant H, Carrau RL, Prevedello D, Gardner $\mathrm{P}$, Kassam AB : What are the limits of endoscopic sinus surgery? the expanded endonasal approach to the skull base. Keio J Med 58: 152-160, 2009.

15) Starke RM : Do brainstem cavernous malformations have a higher rate of hemorrhage? Expert Rev Neurother 15 : 1109-1111, 2015.

16) Takeuchi K, Nagatani $T$, Wakabayashi $T$ : How I do it : shoelace watertight dural closure in extended transsphenoidal surgery. Acta Neurochir (Wien) $157: 2089-2092,2015$.

17) Tubbs RS, Hansasuta A, Loukas M, Louis RG Jr, Shoja MM, Salter EG, Oakes WJ : The basilar venous plexus. Clin Anat 20:755-759, 2007.

18）渡邊 督，永谷哲也，齋藤 清：脳室内および脳室近傍 腫瘍摘出に必要な内視鏡手術解剖。脳外誌 $22: 340^{-}$ 348, 2013.

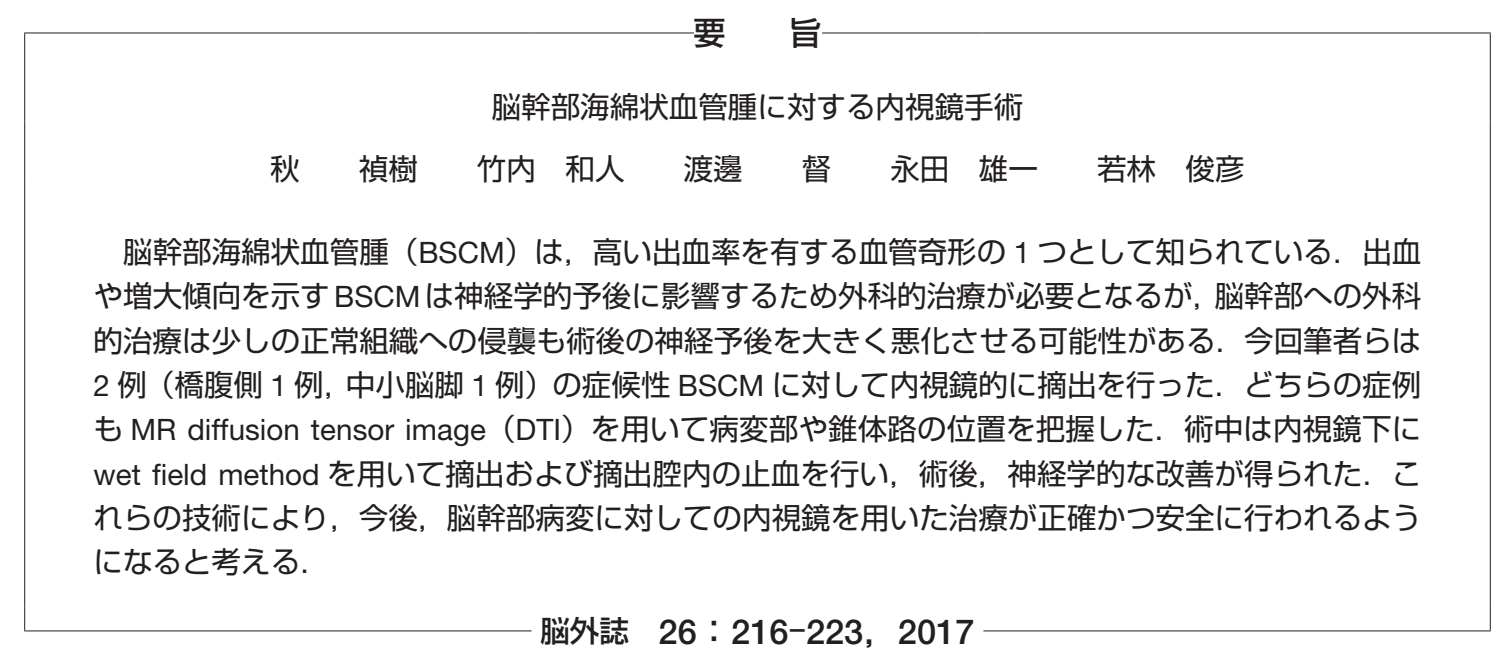




\section{経鼻内視鏡手術による脳幹部海綿状血管腫の摘出術}

脳幹部海綿状血管腫に対しては病変の局在に応じ て適切な手術アプローチが選択されるが，脳幹腹側 病変は手術での到達が最も困難な部位である。解剖 学的には斜台を介した正中からのアプローチが正常 脳幹組織の圧排も少なく, 最も効果的と考えられ る. 近年は内視鏡手術手技が向上し, 経鼻内視鏡手 術による脳幹腹側海綿状血管腫の摘出の有用性が報 告されるようになった。本報告では，内視鏡手術の 経験豊富な施設から, 橋腹側と背側の海綿状血管腫 に対して内視鏡手術で摘出を行って良好な経過を示 した症例の提示と, その手術の工夫が述べられてい る.
九州大学大学院医学研究院脳神経外科 吉本幸司

脳幹部海綿状血管腫の摘出に際しては, 術前画像 により病変の局在と tractography による錐体路の走 行の正確な評価が重要である. 術中のナビゲーショ ンや神経モニタリングが有用なのは開頭術と同様で あるが, 経鼻内視鏡手術では特に深部での操作が中 心になるため, 専用の手術機器と手術テクニックが 必要である。また髄液漏を確実に予防できる手術テ クニックの習得が必要なのはいうまでもなく, 内視 鏡手術の経験豊富な施設で行うべきであろう。橋背 側病変に対する内視鏡手術の適応については議論が あるところであるが，橋腹側病変について経鼻内視 鏡手術は今後有用な手術手技になると考えられる。 